\title{
Absence of the $\alpha$-thalassaemia syndromes in Egyptian Arabs
}

\author{
O. SELIM, K. KAMEL,* F. SABRY, A. IBRAHIM, and D. J. WEATHERALL
}

From The Clinical Pathology Department, Ain-Shams University Medical School, Abbassiah, Cairo, Egypt; El-Galaa Maternity Hospital, Egyptian Ministry of Public Health; and The Department of Haematology, The University of Liverpool, United Kingdom

Summary. An investigation was undertaken to find the incidence of $\alpha$-thalassaemia in Egypt. Blood was collected from the umbilical cords of 550 newborns and from 630 adults from central hospitals in Cairo that drain patients from all over Egypt.

Starch gel electrophoreses at both $\mathrm{pH} 8.6$ and 7.0, and brilliant cresyl blue incubation revealed the absence of haemoglobins Barts and $\mathrm{H}$ in the blood specimens examined.

While much is known on the genetic, clinical, and chemical variations of the $\beta$-thalassaemias and their combinations with other haemoglobinopathies, corresponding information on the $\alpha$-thalassaemias is at best fragmentary and unclear.

It is now an accepted fact that haemoglobins Barts and $\mathrm{H}$ result from a reduction of $\alpha$-chain synthesis, leading to an excess of either $\gamma$ or $\beta$ chains, and hence to the formation of $\gamma_{4}$ and $\beta_{4}$ molecules, respectively.

The incidence of $\mathrm{Hb}$ Barts in cord blood is generally believed to be a reliable index of the prevalance of $\alpha$-thalassaemias in a population (Weatherall, 1963). The frequency of $\mathrm{Hb}$ Barts in some ethnic groups of the old world has been reported and varies widely between them (Weatherall and Clegg, 1972). The occurrence of $49.0 \%$ of $\mathrm{Hb}$ Barts in people of the religious sect, 'The Shiite' (Sheeah) in Saudi Arabia (D. J. Weatherall, R. P. Perrine, and J. R. McNeil, unpublished observations, cited in Weatherall and Clegg, 1972), was interesting and instigated the search for this condition in other Arab populations.

This article presents investigations on the incidence of $\alpha$-thalassaemias in Egypt which comprises about one third of the populations of all Arab

Received 29 January 1974.

* Present address and address for reprints: Sickle Cell Center, Medical College of Georgia, Augusta, Georgia 30902, USA. nations, with the hope that such information would throw more light on these conditions.

\section{Materials and methods}

Five hundred and fifty cord blood samples were collected from El-Galaa Maternity Hospital in Cairo which is a major referral hospital draining maternity cases from all over the country. Heparinized blood samples were usually kept refrigerated overnight and processed during the next day at Ain-Shams University Laboratories.

Blood specimens were also harvested from 630 adult subjects presenting to the out patient clinics of AinShams University Hospitals for various procedures. All specimens were taken from both sexes.

The brilliant cresyl blue incubation was carried out for the detection of $\mathrm{Hb}-\mathrm{H}$ inclusion bodies. Horizontal starch gel electrophoresis was made in tris-EDTA borate buffer system at $\mathrm{pH} 8.6$ and in phosphate system at

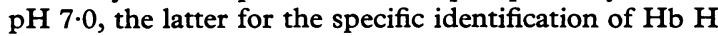
and $\mathrm{Hb}$ Barts. Benzidine or orthodianisidine stain of sliced gels was applied to detect minor electrophoretic fractions. Techniques used are outlined in Weatherall and Clegg (1972).

\section{Results}

Among the 550 cord blood samples examined none showed $\mathrm{Hb}$ Barts in any unequivocally visible proportion on the stained starch gels. From the total specimens of 1180 none had $\mathrm{Hb} \mathrm{H}$ by inclusion body stains and by electrophoretic techniques employed. 


\section{Conclusions}

The only available report on $\mathrm{Hb}$ Barts in Arabs is the one reported above in the Sheeah people of Saudi Arabia. The Arabian peninsula is the largest in the world. It is underpopulated, and various communities in it are separated by vast areas of barren desert, a situation which is most favourable for inbreeding of genetic traits. It is therefore interesting to speculate on the incidence of this haemoglobin in other parts of Saudi Arabia. However, the absence of $\mathrm{Hb}$ Barts in 550 Egyptian newborns suggests it is likely that this $\mathrm{Hb}$ is rare in other Arab communities.

$\mathrm{Hb} \mathrm{H}$ had been sporadically detected in Syrian and Kuwaiti Arabs (Ali, 1969). The scarcity or absence of $\mathrm{Hb} \mathrm{H}$ in Egypt is substantiated by a similar finding in surveys and studies which covered the majority of Egyptian territories (Kamel et al, 1960; Awny, Kamel, and Hoerman, 1965; Kamel, 1968; Azim et al, 1974; Ibrahim et al, 1974; Selim et al, 1974) as well as in neighbouring Libya (Kamel et al, 1975).

It is possible that complete blood counts, indices calculations, and osmotic fragility tests may reveal some mild and/or rare forms of $\alpha$-thalassaemia in those areas.

The allied disorder, $\beta$-thalassaemia has been reported in its homozygous form in $1 / 350$ paediatric patients examined in Cairo (Kamel et al, 1960). In adjacent Libya this condition was not detected in two surveys (Weatherall et al, 1971; Kamel et al, 1975).
This research was supported in part by the Office of Naval Research under contract No. N00014-70-C-0192, NR 108-885.

\section{REFERENCES}

Ali, S. A. (1969). Haemoglobin $\mathrm{H}$ disease in Arabs in Kuwait. Fournal of Clinical Pathology, 22, 226-228.

Awny, A., Kamel, K., and Hoerman, K. (1965). ABO blood groups and haemoglobin variants among Nubians in Egypt, U.A.R. American fournal of Physical Anthropology, 23, 81-82.

Azim, A., Kamel, K., Gaballah, F., Sabry, F., Ibrahim, W., Selim, O., and Moafy, N. (1974). Genetic blood markers and anthropometry of the populations in Aswan governorate, Egypt. Human Heredity, 24, 12-23.

Ibrahim, W., Kamel, K., Selim, O., Azim, A., Gaballah, F, Sabry, F., El-Naggar, A., and Hoerman, K. (1974). Hereditary blood factors and anthropometry of the inhabitants of the Egyptian Siwa Oasis. Human Biology, 46, 57-68.

Kamel, K. (1968). Hemoglobin variants in U.A.R. Journal of the Egyptian Public Health Association, 43, Suppl., 111-117.

Kamel, K., Hoerman, K., Miale, A., and Awny, A. (1960). L'incidence d'hémoglobines congénitalement anormales chez les enfants au Caire, R.A.U. Sang, 31, 307-310.

Kamel, K., 'Umar, M., Ibrahim, W., Mansour, A., Gaballah, F., Selim, O., Azim, A., Hamza, S., Sabry, F., Moafy, N., El-Naggar, A., and Hoerman, K. (1975). Anthropological studies of the Libyan people. Erythrocytes genetic factors, serum haptoglobin phenotypes and anthropometry. American fournal of Physical Anthropology. (In press.)

Selim, O., Kamel, K., Azim, A., Gaballah, F., Sabry, F., Ibrahim, W., Moafy, N., and Hoerman, K. (1974). Genetic markers and anthropometry in the populations of the Egyptian oases of ElKharga and El-Dakhla. Human Heredity. (In press.)

Weatherall, D. J. (1963). Abnormal haemoglobins in the neonatal period and their relationship to thalassaemia. British fournal of Haematology, 9, 265-277.

Weatherall, D. J. and Clegg, J. B. (1972). The Thalassaemia Syndromes, 2nd edition, pp. 228-229, 303-319. Blackwell Scientific Oxford.

Weatherall, D. J., Gilles, H. M., Clegg, J. B., Blankson, J. A Mustafa, D., Boi-Doku, F. S., and Chaudhury, D. S. (1971) Preliminary surveys for the prevalence of the thalassaemia genes in some African populations. Annals of Tropical Medicine and Parasitology, 65, 253-265. 